\title{
Description of the terminal branches of the abdominal aorta in capybaras Hydrochoerus hydrochaeris Linnaeus, 1766 (Mammalia: Rodentia)
}

\section{Erick E. Silveira' ${ }^{1}, *$, Caio Biasi ${ }^{2}$, Amilton Cesar Santos ${ }^{1}$, Helton Carlos Sabino Pereira' ${ }^{1}$, Helen Abud ${ }^{1}$, Antonio Lisboa Neto' ${ }^{1}$, João Marcos Leite ${ }^{1}$ and Antonio Chaves Assis Neto ${ }^{1}$}

\footnotetext{
${ }^{1}$ School of Veterinary Medicine and Animal Science. University of São Paulo. Av. Prof. Dr. Orlando Marques de Paiva, S/№. São Paulo-SP, Brazil (CEP 05508-270).

${ }^{2}$ Department of Anatomy. Patology and Veterinary Clinics. School of Veterinary Medicine and Animal Science. Federal University of Bahia. Rua Augusto Viana, S/No. Palácio da Reitoria. Canela. Salvador-BA, Brazil (CEP 40110-909).
}

Abstract. The capybara Hydrochoerus hydrochaeris Linnaeus, 1766 (Mammalia: Rodentia) is the largest rodent in the world, with great economic potential. Exceeding $80 \mathrm{~kg}$, the animal always lives close to water bodies and its hierarchical flocks have a single dominant male. Current study analyzes the structure and positioning of the terminal branches of the capybara's abdominal aorta to identify clinical pathologies, surgical and radiological procedures, and to contribute towards the knowledge of the rodent's anatomy. The abdominal aorta and its final branches (internal iliac artery, external iliac artery and median sacral artery) of six animals were dissected. Results showed that the organs were very similar to those registered in the literature for other species of rodents.

Keywords: External iliac artery; Internal iliac artery; Median sacral artery.
Received

September 4, 2018

Accepted

November 23, 2018

Released

December 31, 2018

Full Text Article

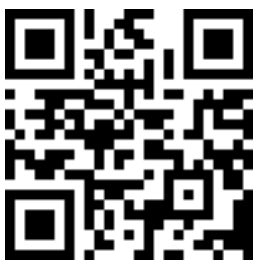

ORCID

D 0000-0001-6755-0064 Erick E. Silveira

(ㄱ) 0000-0001-7476-2583

Caio Biasi

() 0000-0002-0132-6198 Amilton Cesar Santos

(ㄷ) 0000-0002-2158-0513

Helton Carlos Sabino Pereira

D 0000-0002-0664-7177

Helen Abud 


\section{Introduction}

The capybara Hydrochoerus hydrochaeris Linnaeus, 1766 (Mammalia: Rodentia) is the biggest rodent on the planet. It is distributed throughout Central and South America (Adrian and Sachser, 2011). The animals live in hierarchical herds where a single male is dominant. The latter is responsible for most cross breeding (Paula et al., 2002). Body weight may exceed $80 \mathrm{~kg}$ and the male adults have a gland in the brain for the marking of territory (Madella et al., 2006). Water is a must since it is used for haven, copulation and thermal regulation. In fact, they never distance themselves more than $500 \mathrm{~m}$ from any water body (Rocha et al., 2017). The animals are herbivorous and feed on grass and water plants, even though they have a wide range of feed, such as fruit, roots and leaves (Moreira and MacDonald, 1997). Foraging areas depend on food availability (Rocha et al., 2017), whilst their reproduction capacity, fast growth and low cost feed have called the attention of commercial producers for alternative animal protein sources (Antonucci and Ribeiro, 2014). In captivity, they feed on corn, rice, manioc, banana (Moreira and MacDonald, 1997) and even sugarcane. Their simple stomach is capable of efficiently digesting roughage and concentration feed (Felix, 2012).

It is a common sight to detect capybaras on different green areas in urban sites in Brazil (Almeida et al., 2013). They are sometimes considered pests since their occurrence is frequently associated with crop liabilities

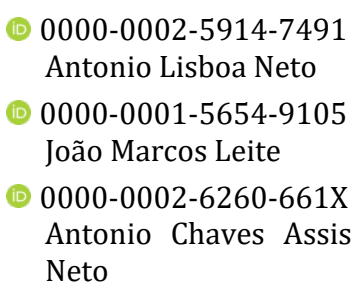

(Antonucci and Ribeiro, 2014), mainly in sugarcane plantations (Felix, 2012). The occurrence of ectoparasites on the animals' bodies is also frequent (Rocha et al., 2017) and one may observe the great amount of birds feeding on the invertebrates near the herds (Almeida et al., 2013).

In-depth studies on capybaras are concerned with ecological, zootechnological and epidemiological aspects, without discarding the role of veterinary medicine. The employment of animals for scientific experimentation is a long-dated practice and this resource has been lately enhanced due to the development of medical techniques and treatments (Fagundes et al., 2004). Rodents already have an important role in the study of disease mechanisms and in the development of pre-clinical assays (Sasaguri et al., 2017). The authors believe that a detailed knowledge of capybara anatomy may be highly useful as a reference. Comparisons are frequently made with regard to apparent similarities with other animal groups through sheer lack of anatomical knowledge.

The description of the abdominal aorta, its terminal branches and the anatomical variations of its structures has an important role in veterinary clinical practice, in surgery and in radiology where related diseases, such as thromboembolism and aneurism, may be diagnosed and treated (Silveira et al., 2018). Current analysis comprises a study of the terminal branches of the abdominal aorta in capybaras and its application in technical-surgical practice. The authors will describe the anatomic 
structure of the terminal branches of the abdominal aorta of the capybara and its variations when compared to those of other species.

\section{Materials and methods}

Current study was performed at the laboratory of Veterinary Anatomy of the Faculty of Veterinary Medicine and Animal Science of the Universidade de São Paulo, within the Postgraduate program in the Anatomy of Domestic and Wild Animals of FMVZ-USP, Brazil. The study was approved by the Committee for Ethics in Animal Experimentation (CEUAVET 6134230518/2018).

Six adult specimens of capybaras Hydrochoerus hydrochaeris $(\mathrm{n}=5$, females and 1 male) were used. Corpses resulted from population control and were donated for research. No animal was submitted to euthanasia, pain or any type of suffering. The abdominal aorta was dissected and immediately catheterized for latex injection with red stain for easy visualization of the vases. The latter were treated with formaldehyde solution $10 \%$. They were maintained submerged in troughs with watery formaldehyde solution for at least $48 \mathrm{~h}$.

Animals were dissected with surgical material and the ventral and lateral abdominal wall was removed from the abdominal cavity. Abdominal viscera and the caudal vena cava were also removed to visualize the cavity, abdominal aorta and its terminal branches. Branches were described according to the Veterinary Anatomic Nomenclature (International Committee on Veterinary Gross Anatomical Nomenclature 2017).

\section{Results}

The terminal segment of the abdominal aorta lay close to the lumbar square muscle and smaller psoas muscle, contacting the ventral surface of the lumbar and sacral vertebras, in syntopy with the caudal cava vena. Termination of the abdominal aorta in all the animals under analysis occurred through ramification on the right and left common iliac artery and median sacral artery. The internal right and left iliac arteries, the external right and left iliac artery and right and left umbilical artery branched as collateral branches of the common iliac artery.

In the above cases, the common iliac artery evolved from the lateral face of the abdominal and cranial aorta towards the source of the internal iliac artery. The two were significantly bigger than the internal iliac artery. The internal iliac arteries revealed a medial trajectory with regard to the external iliac arteries. The median sacral artery in all the specimens evolved from the dorsal face of the abdominal aorta, prior to the bifurcation of the terminal branches, and progressed towards the caudal region.

Termination of the abdominal aorta in the dissected specimens occurred through the branching in the common right and left iliac artery from where the branches of the umbilical arteries emerged, following a medial direction. The common iliac arteries were continued through the external iliac arteries, whereas the animals' internal iliac arteries evolved as a branch of the common iliac artery in its dorsal face (Figure 1). Further, right and left umbilical artery was reported in all dissected specimens. In fact, the artery 

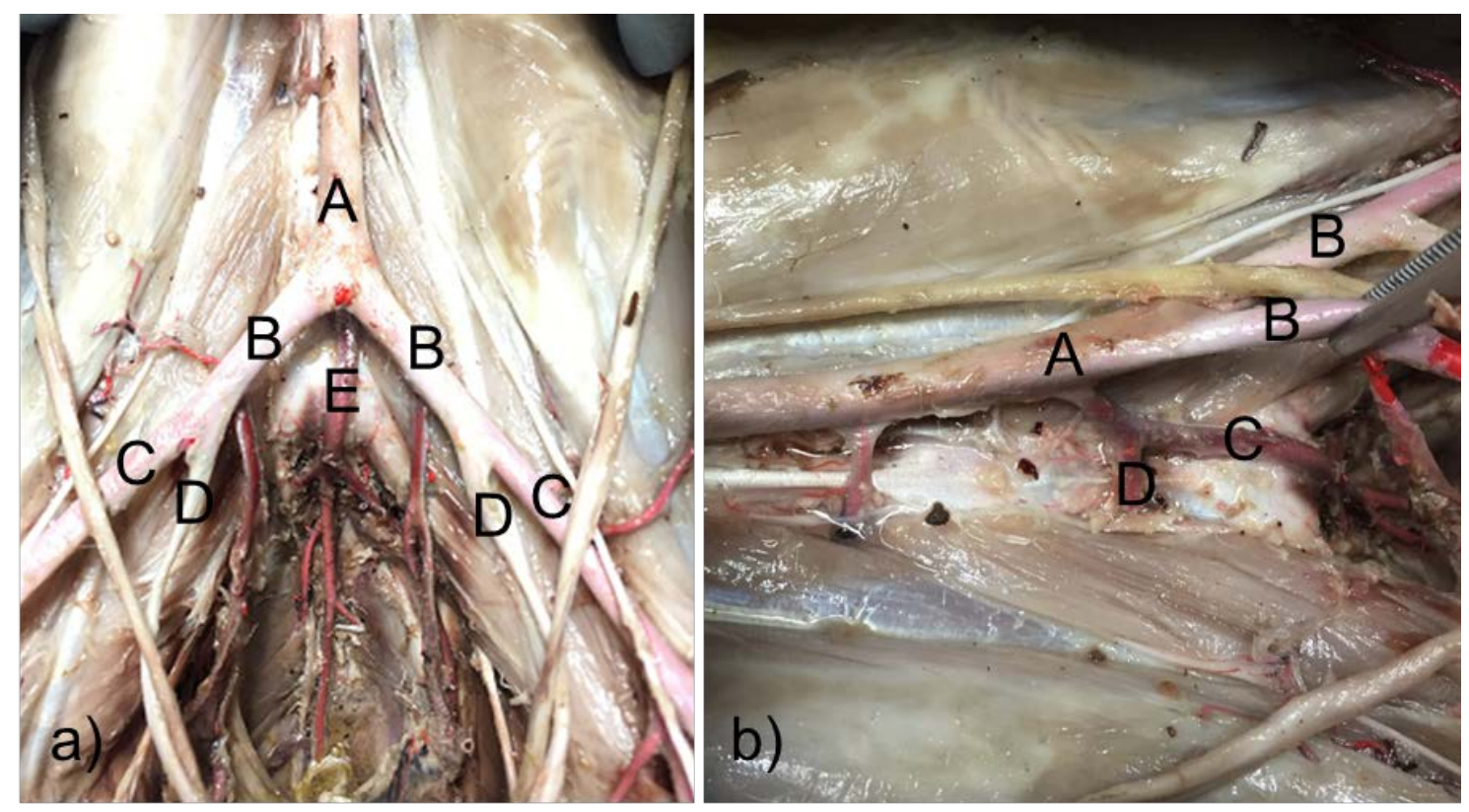

Figure 1. a) Ventral aspect with abdominal aorta (A) evolving into the right and left common iliac artery; (B), right and left external iliac artery; (C) right and left umbilical artery (D); median sacral artery (E). b) Magnification of ventral aspect with abdominal aorta (A) evolving into the right and left common iliac artery (B); median sacral artery (C); lumbar artery (D).

evolved within the medial face of the common iliac arteries, without being pervious.

\section{Discussion}

Current analysis demonstrated that the termination of the abdominal aorta in all specimens studied evolved through the ramification in the right and left common iliac artery and in the median sacral artery. The right and left internal iliac arteries, the right and left external iliac artery and the right and left umbilical artery branched as collateral branches of the common iliac artery. The occurrence of the common iliac artery as the terminal branch of the abdominal aorta has also been reported in marsupials, such as the skunk and the nutria (Myocastor coypus), respectively by Silva and Martins (2004) and Culau et al. (2008). The same description has been given for lagomorphs, such as hares, by Daólio et al. (2011) and Bavaresco et al. (2012).
Macedo et al. (2013) reported a left common trunk in a female anteater, prior to ramifications into external and internal iliac arteries. These results were not registered in the capybaras studied in current analysis.

The external iliac artery was reported by Silva et al. (2011) in the squirrel monkey; by Geraldo et al. (2013) in cats; by Silva et al. (2014) in guinea pigs; by Pinheiro et al. (2014) in ocelots; by Biihrer et al. (2015) in raccoons, as a direct branch from the abdominal aorta on the lateral face. On the other hand, the external iliac artery was described as a branch of the common iliac artery by Silva and Martins (2004) for the skunk; Culau et al. (2008) for the nutria; Daólio et al. (2011) and Bavaresco et al. (2012) for hares. The above agrees with current results on capybaras.

The internal iliac artery was described by Silva and Martins (2004) in skunks; by Silva et al. (2011) in the squirrel monkey; by Silva et al. (2014) in guinea pigs; Faria et al. (2016) in Aotus 
azarae infulatus (owl monkeys), as a branch of the external iliac artery. Biihrer et al. (2015) reported that internal iliac arteries in raccoons evolved as a direct branch from the abdominal aorta. On the other hand, Geraldo et al. (2013) and Pinheiro et al. (2014) described the internal iliac artery evolving from the lateral face of a common trunk, respectively, in cats and ocelots. Daólio et al. (2011) and Bavaresco et al. (2012) and (Culau et al. 2008) reported that the internal iliac artery evolved as a branch of the common iliac artery, respectively, for hares and nutrias. In the case of hares, the internal iliac artery evolved as a branch of the common iliac artery, as reported in current study.

According to Silva and Martins (2004), the median sacral artery in the skunk evolved from the common iliac artery in $30 \%$ of the dissected anatomic models. Further, Macedo et al. (2013) registered that median sacral artery in the anteater evolved as a branch of the left internal iliac artery, with the exception of one specimen in which it evolved from a common trunk. Daólio et al. (2011) and Bavaresco et al. (2012), Silva et al. (2011), Pinto and Silva et al. (2014), Biihrer et al. (2015) and Faria et al. (2016) described median sacral artery as a branch evolving from the dorsal face of the abdominal aorta, respectively, for hares, squirrel monkeys, guinea pigs, raccoons, and night monkeys, corroborating current analysis.

\section{Conclusion}

All specimens studied revealed that the termination of the abdominal aorta occurs from ramification in the right and left common iliac artery and median sacral artery. The right and left internal iliac artery, the right and left external iliac artery and the right and left umbilical artery branched as collateral ramifications of the common iliac artery. Current results agree with those reported for other rodent species in the literature.

\section{Conflict of interest}

Authors declare that they have no conflict of interests.

\section{References}

Adrian, 0.; Sachser, N. Diversity of social and mating systems in cavies: A review. Journal of Mammalogy, v. 92, p. 39-53, 2011. https://doi.org/10.1644/09-MAMM-S-405.1

Almeida, A. M. R.; Arzua, M.; Trindade, P. W. S.; Silva Junior, A. Capivaras (Hydrochoerus hydrochaeris, Linnaeus, 1766) (Mammalia: Rodentia) em áreas verdes do Município de Curitiba (PR). Estudos de Biologia, v. 35, no. 84 , p. 9-16, 2013. https://doi.org/ 10.7213/estud.biol.7845

Antonucci, A. M.; Ribeiro, T. S. Criação comercial de capivara (Hydrochoerus hydrochaerys) no Brasil. Archhivos de Zootecnia, v. 63, p. 189-198, 2014. https://doi.org/10.21071/az.v63i241.598

Bavaresco, A. Z.; Culau, P. O. V.; Campos, R. Ramos colaterais parietais e terminais da aorta abdominal em coelhos da raça Nova Zelândia (Oryctolagus cuniculus). Acta Scientiae Veterinariae, v. 40, no. 4, p. 1-6, 2012. Available from: <http://www.ufrgs.br/ actavet/40-4/PUB 1069.pdf>. Accessed on: Apr. 23, 2018.

Biiher, D. A.; Guimarães, G. C.; Lopes, G. C.; Lima, I. G. Descrição anatômica dos ramos artérias da aorta torácida e abdominal do quati (Nasua nasua). Biotemas, v. 28, no. 2, p. 119-124, 2015. https://doi.org/10.5007/ 2175-7925.2015v28n2p119

Culau, P. O. V.; Azambuja, R. C. A.; Campos, R. Ramos colaterais parietais e terminais da aorta abdominal em Myocastor coypus (nutria). Ciência Rural, v. 38, no. 4, p. $997-$ 1002, 2008. https://doi.org/10.1590/S010384782008000400014

Daólio, M.; Marchi, P. N.; Pinto e Silva, J. R. C.; Guazzelli Filho, J.; Schimming, B. C.; Matheus, S. M. M.; Filadelpho, A. L. Estudo dos ramos sacrais da aorta abdominal do coelho (Oryctolagus cuniculus). Revista Científica Eletrônica de Medicina Veterinária, v. 9, no. 17, p.1-10, 2011. Available from: <http://faef.revista.inf.br/imagens_arquivos/ arquivos_destaque/OSncll3e8ltsUu2_2013-619-17-31-57.pdf $>$. Accessed on: Apr. 23, 2018. 
Fagundes, D. J.; Taha, M. O. Modelo animal de doença: critérios de escolha e espécies de animais de uso corrente. Acta Cirurgica Brasileira, v. 19, no. 1, p. 59-65, 2004. https://doi.org/10.1590/S0102-86502004 000100010

Faria, B. M.; Branco, E.; Lima, A. R. Ramos da aorta abdominal de Aotus azarae infulatus. Biotemas, v. 29, no. 2, p. 69-76, 2016. https://doi.org/10.5007/2175-7925.2016 v29n2p69

Felix, G. A. Comportamento alimentar e qualidade de carne de capivara (Hydrochoerus hydrochaeris Linnaeus, 1766) de vida livre, em áreas agrícolas. Dourados: Universidade Federal da Grande Dourados, 2012. (Dissertação de mestrado).

Geraldo, B.; Pinto e Silva, J. R. C.; Schimming, B. C.; Guazzelli Filho, J.; Filadelpho, A. L. Contribuição ao estudo anatômico dos ramos sacrais da aorta abdominal do gato (Felis catus). Revista Científica Eletrônica de Medicina Veterinária, v. 11, no. 20, 2013. Available from: <http://faef.revista.inf.br/ imagens_arquivos/arquivos_destaque/OSncIl 3e8ltsUu2_2013-6-19-17-31-57.pdf>.

Accessed on: Apr. 23, 2018.

International Committee on Veterinary Gross Anatomical Nomenclature. Nomina Anatômica Veterinária. 5. ed. Hannover: Editorial Committee, 2017.

Macedo, B. C.; Lima, A. R.; Pereira, L. C.; Branco, E. Descrição morfológica dos ramos colaterais da aorta abdominal do tamanduámirim (Tamandua tetradactyla). Biotemas, v. 26, no. $1, \quad$ p. 173-180, 2013. https://doi.org/10.5007/2175-7925.2013 v26n1p173

Madella, D. A.; Rodrigues-Neto, E. J.; Felisberto, M. E.; Souza, C. E. Valores hematológicos de capivaras (Hydrochoerus hydrochaeris) (Rodentia: Hydrochoeridae) de vida livre na região de Campinas-SP. Ciência Rural, v. 36, no. 4, p. 1321-1324, 2006. https://doi.org/10.1590/S0103-847820060 00400046

Moreira, J. R.; MacDonald, D. W. Técnicas de manejo de capivaras e outros grandes roedores na Amazônia. In: Valladares-Pádua, C.; Bodmer, R. E. (Eds.). Manejo e conservação da vida silvestre no Brasil. Brasília: Sociedade Civil Mamirauá, 1997. p. 186-213.

Paula, T. D.; Costa, D. S.; Matta, S. L. P. Avaliação histológica quantitativa do testículo de capivaras (Hydrochoerus hydrochaeris) adultas. Bioscience Journal, v. 18 n. 1, p. 121-136, 2002. Available from: <http://www.seer.ufu.br/index.php/bioscien cejournal/article/view/6397/4134>.

Accessed on: Apr. 23, 2018.

Pinheiro, L. L.; Araújo, E. B.; Lima, A. R.; Martins, D. M.; Melul, R.; Souza, A. C. B.; Pereira, L. C.; Branco, E. Os ramos colaterais da aorta abdominal em jaguatirica (Leopardus pardalis). Pesquisa Veterinária Brasileira, v. 34, no. 5, p. 491-495, 2014. https://doi.org/10.1590/S0100-736X20140 00500018

Rocha, V. J.; Sekiama, M. L.; Gonçalves, D. D.; Sampieri, B. R.; Barbosa, G. P.; Dias, T. D. C.; Rossi, H. R.; Souza, P. F. P. D. Capivaras (Hydrochoerus hydrochaeris) e a presença do carrapato (Amblyomma sculptum) no campus da UFSCAR, Araras, São Paulo. Ciência Animal Brasileira, v. 18, 1-15, 2017. https://doi.org/10.590/1089-6891v18e44671

Sasaguri, H.; Nilsson, P.; Hashimoto, S.; Nagata, K.; Saito, T.; Strooper, B. D.; Hardy, J.; Vassar, R.; Winblad, B.; Saido, T. C. APP mouse models for Alzheimer \& disease preclinical studies. The EMBO Journal, v. 36, no. 17 , p. 2473-2487, 2017. https://doi.org/ 10.15252/embj.201797397

Silva, J. R. C. P.; Guazzelli Filho, J.; Shimming, B. C.; Filadelpho, A. L.; Jesus, L. S. B. Estudo anatômico dos ramos sacrais da aorta abdominal da cobaia (Cavia porcellus). Revista Científica Eletrônica de Medicina Veterinária, v. 12, no. 23, 2014. Available from: <http://faef.revista.inf.br/imagens_ arquivos/arquivos_destaque/xj6JVLgZsxusE MY_2014-7-27-17-16-49.pdf>. Accessed on: Apr. 23, 2018.

Silva, J. R. C. P.; Martins, M. R. F. B. Anatomical study of the abdominal aorta sacral rami of the opossum (Didelphis albiventris). International Journal of Morphology, v. 22, no. 3, p. 217-220, 2004. https://doi.org/ 10.4067/S0717-95022004000300007

Silva, M. R. M.; Lima, A. R.; Lacreta Júnior, A. C. C.; Ishizaki, M. N.; Imbeloni, A. A.; Muniz, J. A. P. C.; Branco, E. R. Descrição morfológica dos ramos colaterais viscerais da aorta abdominal do macaco-de-cheiro. Ciência Rural, v. 41, no. 1, p.94-100, 2011. https://doi.org/10.1590/S0103-84782011 000100015 
Silveira, E. E.; Santos, A. C.; Abud, H.; Prazeres, R. F.; Biasi, C. Description of terminal ramifications of the abdominal aorta in dogs (Canis familiaris). Revista Científica de Medicina Veterinária, v. 10, p. 1-8, 2018. Available from: <http://faef.revista.inf.br/ imagens_arquivos/arquivos_destaque/gkS2o siYi9EF8ep_2018-7-6-10-45-45.pdf>.

Accessed on: Apr. 23, 2018. original work is properly cited. 